The shortage of natural rubber, which is so important for military purposes in this age of mechanization, has stimulated research on the possibility of producing rubber from plants that can be grown on the American continent. Synthetic rubbers of various types are being developed and tested, and plants are being established for the production of the more useful types.

\section{SCIENTIFIC PROGRESS SINCE 1840}

TN a lecture, "A Century of Progress : Men, Manners, Inventions", given before the Lancastrian Frankland Society on January 15, Dr. E. F. Armstrong drew a stimulating comparison between the conditions of Edward Frankland's early years in Lancaster and to-day. Referring to the encouragement which Frankland received from the Johnsons in Lancaster, who sent him to Playfair in 1845, Dr. Armstrong remarked that the energy to get on in spite of the most adverse and discouraging circumstances was characteristic of the 1840 's. A deep interest in Nature and in intellectual matters was also widespread in the north of England during the Victorian period and led to the formation of many local societies, ranging from the mutual improvement societies of the chapels to the mechanics institutes and literary and scientific societies of the small towns and the philosophical societies of the large cities. These societies, which besides spreading knowledge gave inspiration to the younger members, persisted until improved communications, a multitude of technical journals and the spread of technical colleges drove most of them out of existence, although even now technical societies with local sections have a most important function.

Frankland apparently took up science as a career through his parents instilling a spirit of inquiry and the desire to find out things for oneself. Commenting on the fact that the period 1840-70 saw the birth and entry into the sciences of a great many men from very diverse walks of life, whose achievements have laid the foundations on which we are building to-day, Dr. Armstrong directed attention to the early life of austerity and struggle which developed their powers. Among these were James Dewar, Horace and Adrian Brown, Charles Lapworth, Richard Threlfall, Alfred Yarrow, Bates of Amazon fame, C. F. Cross, James Alfred Ewing, and H. B. Baker.

The chief characteristics of the last hundred years, Dr. Armstrong suggested, are the inventions and discoveries which have so markedly affected the material progress of the world that they may well be regarded as the seven modern wonders of the world, superseding the seven architectural wonders of the past. The first of these is pure water supply, in the provision of which. Frankland himself played a large part. As a scientific member of the Royal Commission appointed in 1867, he found that the oxidation and destruction of the organic matters present in town drainage took place with extreme slowness, contrary to the previous belief. He found, on the other hand, that slow percolation through porous soil effected this oxidation and destruction with great rapidity. Frankland also improved the old and devised new methods of water analysis, and throughout his life took special interest in the water supply of London, while his son, Percy Frankland, took up the study of the biological aspects of the problem. Continuing this work, Sir A. C. Houston, the pioneer of systematic chlorination treatment on a large scale, was also responsible for the scientific application of bacteriology for improving and safeguarding the purity of water. Dr. Armstrong referred here to his previous suggestion that a tablet commemorating these achievements of Frankland should be placed on the great new dam across Hawes-water.

Second of the modern seven wonders, both in point of time and importance to pure water, must be ranked electricity, which from its gradual development, starting with its use in signalling by Cook and Wheatstone, with no encouragement by the State, has now become a major industry touching almost every home. The third wonder was the spinning of viscose or Rayon from wood, with the consequent revolution in women's dress. Even now we are only at the beginning, the newest of all these fibres being Nylon, a wholly synthetic fibre, built up as it were from carbon, water and air, with properties as good or better than those of silk spun by the silkworm.

The fourth and fifth wonders, the internal combustion engine and hydrocarbon oil, are so interdependent that they may well be considered together. Giving us speedy transport on land, on sea and in the air, they have made the world one community. Speedy travel has had great political repercussions; and no individual, community or nation can withdraw at will to a quiet corner to follow its own inclinations. The development of the internal combustion engine was based on progress in design correlated with progress in metallurgy, while the oil industry was providing raw materials for many diverse chemical operations and was destined to displace coal tar and coal as the world's most important basic raw material for chemical synthesis - probably with further effects on our own post-war economy following on those already involved in the displacement or disappearance of cheap coal.

Next among modern wonders came the radio, which is enabling all to lead a fuller and broader life. Its cultural and scientific significance is not yet fully appreciated, and despite its importance in war the future applications may be astounding. The last wonder, Dr. Armstrong said, was the plastics, of which the man in the street is as yet only dimly conscious, although they are destined to make life easier for us all, to provide objects of utility, and should alsamake artistic design and beauty available at prices diminishing rather than increasing. Finally, Dr. Armstrong pointed out that the satisfactory solution of the problems of society into which science enters will be based on moral influence, and our effectiveness will depend on the devotion, wisdom and goodwill which we bring to our task.

\section{A SPREAD-SCALE RECORDER}

$\mathrm{TN}$ an article with this title (Bell. Lab. Rec., 21, No. 1 3 ; November 1942) O. D. Engstrom points out that the transmission tolerances of telephone circuits have become more severe, requiring a corresponding improvement in measuring technique and equipment. When a telephone circuit had only a few amplifiers or other circuit units, each could be permitted a larger share of the total permissible distortion, and errors in measurement of $0.25 \mathrm{db}$. meant very little. With the present transmission systems requiring many more circuit units than the earlier systems, this situation has changed. More accurate and faster operating testing equipment has been required, and 
a recording transmission-measuring set was developed that covers the voice-frequency spectrum in a few minutes. As originally used, the chart of this recorder could be read to about $0.2 \mathrm{db}$., but for many presentday measurements this is not adequate, and a new 'spread-scale' recorder has been developed that can be read to $0.02 \mathrm{db}$.

For a transmission measurement, an adjustablefrequency oscillator is provided with a small synchronous motor that changes the output frequency continuously over the range from 200 to 3,500 cycles for each test. An equalizer and adjustable attenuator in the output of the oscillator maintain the output power constant at the desired level for the test. At the output of the circuit being measured is an I-U amplifier-rectifier that converts the received A.c. into D.C. for operating the recorder. A 500 cycle selective detector is employed to mark the chart at a point corresponding to a test frequency of 500 cycles, and this mark is used in placing the frequency ordinates on the chart. A biasing circuit was added as one of the changes required to produce the spread-scale characteristic.

To secure the added precision needed for a chart that is to be read to $0.02 \mathrm{db}$., certain other changes were made, including principally an increased voltage stability of the power supplies and an increased stability of the oscillator output and of the detector gain as the frequency varied over the test range. Steps taken to improve the circuit in these respects include the provision of a regulated plate-battery power supply for both the oscillator and the detector, storage battery for filament supply, the selection of quiet tubes, and special regulation for the oscillator output characteristics.

The circuit is calibrated by applying an input of $10 \mathrm{db}$. below 1 milliwatt to the amplifier-rectifier, and then adjusting the resistance in the circuit of the biasing battery until a mid-scale deflexion is obtained. When making a measurement of the transmission characteristic of a piece of equipment, it is then necessary to adjust the oscillator output so that the output of the equipment under test is $10 \mathrm{db}$. below 1 milliwatt at roughly the frequency of the mean attenuation. The dial of the oscillator is then set below the edge of the desired band, and the oscillator and recorder are both started. The article describes and illustrates the recorder and its performance characteristics in detail.

\section{FORTHCOMING EVENTS}

(Meetings marked with an asterisk are open to the public)

Saturday, February 27

Madacological Socretr (at the Linnean Society, Burlington House, Piccadilly, London, W.1), at 2.30 p.m.-Annual General Meeting and Commemoration of the 50th Anniversary of the Society's Foundation.

Light RAILWAY TRANSPORT LEAGUE (at Fred Tallant Hall, Room J,

Drummond Street, London, N.W.1), at 3 p.m.-Dr. Hugh Nicol: “A' Drummond Street, London, N,;

\section{Monday, March I}

FARMers' CuUB (at the Royal Empire Society, Craven Street, Strand, London, w.C.2), at 2.30 p.m.-Sir William Prince-Smith, Bart. : "An Industrialist's Views on Agriculture and its Future".

\section{Tuesday, March 2} MANChester IITkRary AND PHITosopaical Socrery (in the Geographical Department, The University, Manchester), at 5 p.m."

INSTITUTE of WELDing (at the Institution of Hechanical Engineers Storey's Gate, St. Janies's Park, London, S.W.1), at ' 6 p.m. $=$ A serie of Papers on "Developments in Arc Welding Technique".
Wednesday, March 3

ROYAL Socrety of ARTs (at John Adam Street, Adelphi, London, w.C.2) at 1.45 p.m.-Dr. J. D. Robertson : "Calcium Metabolism W.C.2), at 1.45 p.m.-D.

PHYSICAL Societr (COLOUR GROUP) (in the Lecture Theatre of the Science Museum, Exhibition Road, London, S.W.7), at 2.30 p.m.Third Annual General Meeting. At 3 p.m. -Mr. $J$. Guild: "The Significance and Limitations of the C.I.E. Standard Observer Tables". INSTITUTE OF METALS (at the Institution of Mechanical Engineers, Storey's Gate, St. James's Park, London, S.W.1), at 3 p.m.-35th Annual General Meeting. Dr. Harold Moore: "Co-operative Research in the Metal Industries;

INSTITUTION OF MEChanical ENgINEeRs (JOINT MEETING WITH THE IRON AND STEEL INSTITUTE AND THE INSTITUTE OF METALS) (at Storey's Gate, St. James's Park, London, S.W.1), at 5.30 p.m.-Dr. S. W. Smith:" "The Life and Work of Sir William Chandler RobertsAusten".

Thursday, March 4

InSTITUTION of Electrical ENGINGERs (at Savoy Place, Victoria Embankment, London, W.C.2), at 5 p.m. Sound Films of Honorary Members and Faraday Medallists $\rightarrow$ Sir J. J. Thomson, O.M., F.R.S.; Lord Rutherford, O.M., F.R.S.

\section{Friday, March 5}

ROYAL SOCIETY OF ARTS (INDIA AND BuRMA SECTION) (at John Adam Street, Adelphi, London, W.C.2), at 1.45 p.m. - Sir Malcolm Darling : "The Indian Village and Democracy".

RoYAL InSTITUTION (at 21 Albemarle Street, London, W.1), at 5 p.m.-Sir John Russell, F.R.S.: "Restarting of Agriculture in Devastated Europe".

\section{Saturday, March 6}

Geologists' Association (at the Geological Society of London Burlington House, Piccadilly, London, W.1), at 2.30 p.m.-Annua General Meeting. Prof. H. H. Read, F.R.S.: "Meditations on Granite" (Presidential Address)

\section{Friday, March 5-Sunday, March 7}

INSTITUTE of INDUSTRIAI ADMinistration (at the Waldorf Hotel Aldwych, London, W.C.2). Conference on "Training for Industrial Management"."

Friday, March 5

4.30 p.m.-Registration of Members.

Saturday, Marci' 6

10 a.m.-Management and the Nation. bury.

12.30 p.m.-Management and Industry.

p.m.-External Training for Industry.

$5.30 \mathrm{p} . \mathrm{m}$.- - Internal Training in Industry.

Sunday, March 7

10 a.m-Management and the Board Room.

11.30 a.m.-Review of Conference.

\section{APPOINTMENTS VACANT}

APpLICATIONs are invited for the following appointments on or before the dates mentioned

LECTURER-INSTRUCTOR IN ENGINEERING WORKSHOP TEOHNOLOGY Lolton Municipal Technical College-The Director of Education, Education Offlces, Nelson Square, Bolton (March 5).

Master to Teach Mathematics AND SoIence at the Bingley MASTER TO TEACH MATHEMATICS AND Scational Officer, Education Technical School-The Divisional

Lecturer in MECHANICAL ENGINEering in the Oxford Schools of Technology, Art and Commerce-The Chief Education

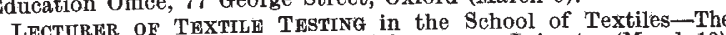
LECTURER OF of Technology and Commerce, Leicester (March 13).

Charr of Chemistry in the University College of North WalesChair of College of North Wales, The Bursar and

(either sex) for Crop Investigations of Assistant FIELD OFFICER (either sex) for Crop Investigations of Kent.

Assistant (woman) FOR THE STRAWBERRY NUCrian STOck ASSISTANT (Wecretary, Research Station, East Malling, Kent.

Troinical Assistant (male or female) IN THE DEPaRTManT of TECHNICAL Assis ant (mouth-Eastern Agricultural College, Wye Kent.

AgstsT. ENGINEERS for operation and maintenance of hydroAssistavic Supply Company, Nigerian Plateau-The Ministry of Labour and National Service, Central (Teehnical and Selentife) Regiter, Section D.553X, Alexandra House, Kingsway, London, W.C.2.

In Mechantcal Engrnebring-The Secretary, Woolwich ILOTURER WN Modwich, London, S.I.18. 